\title{
Contribution to a Study of the Effect of the Essential Oil of Henna (Lawsonia inermis L), on the Biological Aspect of White Scale (Parlatoria blanchardi targ) of Date Palm
}

\author{
Keltoum Benaissa ${ }^{1,2^{*}}$, Mohamed Belhamra ${ }^{1,2}$ \\ ${ }^{1}$ Laboratory of ecosystem diversity and dynamics of agricultural production systems in arid areas. Biskra University, ALGERIA. \\ ${ }^{2}$ Department of agronomics sciences, faculty of sciences of nature and life, Biskra University, ALGERIA
}

\begin{abstract}
The study was carried to evaluate the effect of the essential oil of henna's leaves on the biological aspects (egg, larvae and adults stages) of Parlatoria blanchardi. The insect is one of the serious pest infected the date palm cultivated in Algeria. The sample of leaves of date palm infested by the insect putted in Petri dishes were treated under the laboratory conditions with 05 treatments $(\mathrm{C} 0, \mathrm{C} 1, \mathrm{C} 2, \mathrm{C}+, \mathrm{C}-)_{\text {; }}$ two were obtained by the dilution of the essential oil (the concentration of $5 \%$ and $20 \%$ of essential oil) and three controls (two negative controls and an insecticide as positive control). The results obtained in the earliest 06 days of the experimentation, showed that the two treatments of the essential oil caused high mortality on different stages of Parlatoria blanchardi, close to those obtained with the control with a delay of one day.
\end{abstract}

Keywords: Bioinsecticide, Essential oil, White scale, Serious pest, Laboratory conditions, High mortality.

\section{INTRODUCTION}

Discovered in 1868 by. Blanchard M.E., in an oasis of the Oued-Righ, in the Algerian Sahara. White scale, caused by Parlatoria blanchardii Targ. is widely present in most date palm growing areas of the world. It is considered a serious pest in Algeria. There are no date palm areas free from the attack of Parlatoria blanchardi. ${ }^{1}$ Damage by white scale is very serious on young palms between two to eight years of age, but even under severe attacks, the palm and its offshoots do not die, Nymphs and adults suck the sap from the leaflet, midribs and the dates. Under each scale insect, a discolored area appears on the leaflet. Heavy infestation causes leaflets to turn yellow and contributes to the premature death of the fronds. ${ }^{2}$ In recent years, the importance of essential oils as biocides and insect repellents has led to a more detailed study of their antimicrobial potential. ${ }^{3}$ Since the last century the henna flowers named "Faghia" were used as bio insecticide to protect the wool against worms that may develop in it. ${ }^{4}$

Our work consists in studying the effect of essential oils of henna's leaves (Lawsonia inermis L) on the evolution of populations (egg stage, larvae and adult) of the white scale (Parlatoria blanchardi) of the date palm.

\section{MATERIAL AND METHODS}

\section{Plant material}

The sample of fresh leaves is collected from shrub of henna cultivated in a village based in Sidi Okba (department of Biskra Algeria) on March 2016.

\section{Animal material}

The animal material consists of individuals of Parlatoria blanchardi on palms took from the medium foliage of a young date palm,
DOI: 10.5530/ijper.51.3s.36 Correspondence: Keltoum Benaissa, Laboratory of ecosystem diversity and dynamics of Agricultural production systems in arid areas. Biskra University, ALGERIA.\& Department of agronomics sciences, faculty of sciences of nature and life, Biskra University, ALGERIA

Tel: +213 775840016 ; E-mail: miskelil07@gmail.com 
cultivated in Agronomics Sciences Department, University of Biskra.

\section{Insecticide}

The insecticide used as positive control is the petroleum oil, which is used frequently by farmers to treat against Parlatoria blanchardi.

\section{METHODS}

The extraction of essential oil was carried out by the hydro-distillation type Clevenger, we weighted $750 \mathrm{~g}$ of fresh leaves were placed in a flask of $2 \mathrm{~L}$ containing $1.5 \mathrm{~L}$ of distilled water at temperature of $100^{\circ} \mathrm{C}$ during $4 \mathrm{~h}$. The organic layer was separated from the water than the distillate was dehydrated using anhydrous sodium sulfate

\section{Yield of essential oil}

The yield of essential oil is defined as the ratio between the mass of essential oil obtained and the mass of the plant material to be treated. ${ }^{5}$

\section{Treatments preparation}

We tested during our study two dilutions from the extracted essential oil by adjusting the volume with ethanol: $\mathrm{C}_{1}$ dose: The less concentrated dilution with $5 \%$ of essential oil; and the $\mathrm{C}_{2}$ : dose with $20 \%$ of essential oil. The dose $\mathrm{C}+$ (the positive control) was obtained by taking $0.1 \mathrm{ml}$ of insecticide adjusted to $100 \mathrm{ml}$ of ethanol. The two last treatment were the negative control C- equivalent volume of ethanol, and the C0 applying only the equivalent volume of water.

All the treatments prepared were sprayed on the leaves, and covered by the lid of Petri dishes.

\section{Estimation of the infestation}

The EUVRETE method $^{6}$ was used to estimate the infestation rate of each leaflet taken and returned to the laboratory. This consists of choosing $3 \mathrm{~cm}^{2}$ on the upper face of the leaflet. All the individuals of the different stages (egg, larvae and adult stages) were counted under a binocular (X 50)

\section{Statistical analysis}

Statistical analyzes were performed using the Statistica version 8 software, which allowed the analysis of variance (ANOVA) in two ways and the comparison of means by the Fisher LSD test.

\section{RESULTS AND DISCUSSIONS}

\section{The yield of essential oil}

The yield of extracted essential oil from henna leaves was $1.06 \%$. This result is improved; it is more than obtained by Rahmat et al, where it was $0.83 \%$.

\section{The effect of treatments on different stages of $P$. blancharidi life}

The effect of the two dilutions of essential oil and the three controls are summarized in Table 1 and Figure 1. From those results, we can deduce that the effect of $\mathrm{C}+$ appear after one day of treatment spraying on larvae and adult stages. Focusing on the $4^{\text {th }}$ day of the experiment we can deduce that the stage egg is the more resistant; at the time when the number of larvae and adults is reduced $100 \%$ on this day the eggs are not affected by the insecticide.

Chemical control using insecticides to treat against P. blanchardi caused mortality percentages of 73.2 and 80.0 according to the plot. Biological control using beetles resulted in mortality percentages of 18.1 and 19.7. The use of bio-insecticide can be the ideal alternative of chemicals because those affected the pest but also the auxiliary. ${ }^{8}$

Other experiment that study the effect of different extracts from the leaves of L. inermis against blowfly, showed that the egg stage of the insect was the most resistant stage to all plants extract that used especially water and hexane extracts, and the highest mortality

\begin{tabular}{|c|c|c|c|c|c|c|c|c|}
\hline \multirow[b]{2}{*}{ Treatments } & \multicolumn{4}{|c|}{ Larvae stage } & \multicolumn{4}{|c|}{ Egg stage } \\
\hline & j1 & J2 & j4 & j6 & j1 & j2 & j4 & j6 \\
\hline $\mathrm{CO}$ & $1361.25 \mathrm{~F}$ & $971.5 \mathrm{D}$ & $381.5 \mathrm{~B}$ & $0.0 \mathrm{~A}$ & $681 \mathrm{~J}$ & $487.75 \mathrm{E}$ & $347.25 \mathrm{D}$ & $0.0 \mathrm{~A}$ \\
\hline $\mathrm{C} 1$ & $1355 \mathrm{~F}$ & $650.75 \mathrm{D}$ & $421.5 \mathrm{~B}$ & $0.0 \mathrm{~A}$ & $678.5 \mathrm{~J}$ & $322 \mathrm{D}$ & $206.5 C$ & $0.0 \mathrm{~A}$ \\
\hline C2 & $1330 \mathrm{~F}$ & $386.75 \mathrm{~B}$ & $5.75 \mathrm{~A}$ & $0.0 \mathrm{~A}$ & $666.25 F$ & $193.5 \mathrm{C}$ & $50.75 B$ & $0.0 \mathrm{~A}$ \\
\hline $\mathrm{C}+$ & $1215.75^{\mathrm{E}}$ & $19.75 \mathrm{~A}$ & $0.0 \mathrm{~A}$ & $0.0 \mathrm{~A}$ & $685.75 \mathrm{~J}$ & $10 \mathrm{E}$ & $342.25 \mathrm{D}$ & $0.0 \mathrm{~A}$ \\
\hline C- & $1356.25 \mathrm{~F}$ & $976.5 \mathrm{D}$ & $663.5 \mathrm{C}$ & $0.0 \mathrm{~A}$ & $617 \mathrm{~F}$ & $387.25 \mathrm{E}$ & $0.0 \mathrm{~A}$ & $0.0 \mathrm{~A}$ \\
\hline
\end{tabular}

Mean values followed by the same letter in the same column are not significantly different according to the Fischer LSD test at $P<0.05$. 


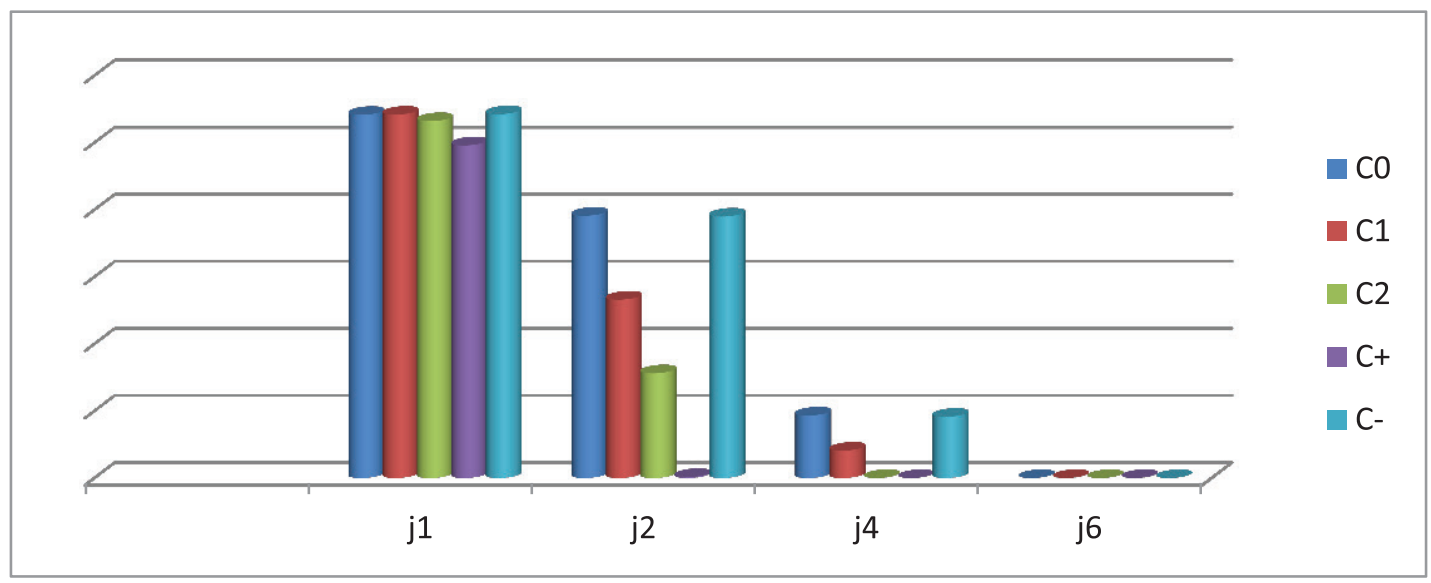

Figure 1: The effect of the treatments on the number of the adult stage.

percentage was recorded with the crude extract of L. intermis on $100 \%$ concentration. ${ }^{9}$

\section{CONCLUSION}

The main result of this study is that the essential oils extracted from henna leaves can affect on $P$ blanchardi. The concentration of $20 \%$ of essential oil can induce mortality of larvae and adult stage delayed by one day from the $\mathrm{C}+$. This experimentation should be conducted on field in order to obtain results applicable by farmers.

\section{ACKNOWLEDGEMENT}

The authors would like to thank the farmer Abdelkacem S, from Sidikhelil village for the samples of henna plant used in this study, we thank also Hantiz S. and Tahraoui S., post graduate students with all the technical stuff of plant production laboratory, Agronomics sciences department, University of Biskra .Algeria.

\section{CONFLICT OF INTEREST}

None

\section{ABBREVIATION USED}

C1: $5 \%$ of essential oil; C2: $20 \%$ of essantial oil; C+: volum of petrolium oil; $\mathrm{C} 0$ : volume of water; C-: vol- ume of ethanol; J1-J2-J4-J6: 1st-2nd-4th-6th day after treatment.

\section{REFERENCES}

1. Allam A. Infestation du palmier dattier par Parlatoria blanchardi. Editions universitaires europeennes. 128P.

2. Zaid A, Wet PE, Djerbi M, Oihabi A. Date palm cultivation, Chapter Xii: Diseases and pests of date palm. 2002 http://www.fao.org/docrep/006/ Y4360E/y4360e0g.htm.

3. Schmidt E. Production of essential oils. Handbook of essential oils. Science, technology and applications. Edited by K. Hüsnü Can Bas,er Gerhard Buchbauer; 2010

4. Vonderheyden M. Le henné chez les musulmans de l'Afrique du Nord (Suite et fin). In: Journal de la Société des Africanistes. doi : 10.3406/jafr.1934.1574.

5. AFNOR: Huiles essentielles. Ed. PARA Graphic. Tome1 - Echantillonnage et méthode d'analyse $471 \mathrm{P}$. Tome 2 - Volume 1 Monographie relative aux huiles essentielles 323 P. 2000

6. Idder-Ighili H, Idder MA, Hamad BM, Doumandji-Mitiche B. Relations entre la cochenille blanche Parlatoria blanchardi targiono-tozzetti (homopteradiaspididae) et quelques varietes de dattes a ouargla (sud-est algerien). Revue des Bio Ressources. 2013;3(1):32-40.

7. Rahmat A, Edini S, Ismail P, Hin TY, Baker AMF. Chemical constituents, antioxidant activity and cytotoxic effects of essential oil from Strobilanthes cripus and Lawsonia inermis. Journal of biological sciences. 2006;6(6):1005-10.

8. Idder MA, Doumandji-Mitiche B, Pintureau B. Biological Control in Algerian Palm Groves.Proc. First IS on Date Palm, Eds.: N. Bouguedoura et al. Acta Hort. 994, ISHS 2013;347-54.

9. Akbar MM, AL-Mansour NA, AL-Edani AA. Effect of plant extract of the leaves of lawsonia intermis $L$. and the peel Quercus infectoria oliv, on the biological aspect of the blowfly lucilia sericata (Diptera : Calliphoridae). Journal El Basra Sciences. 2011;29(1):8-23 


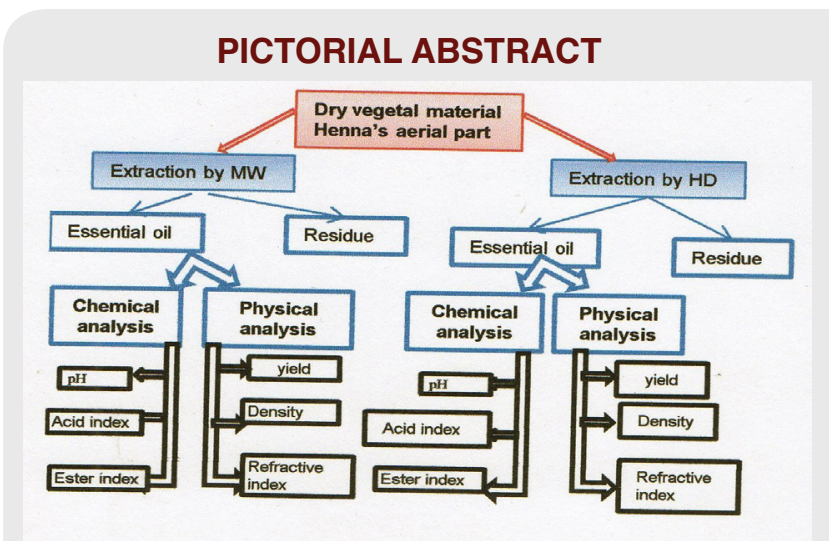

\section{SUMMARY}

- The aromatic oil extracted from the leaves and the seed of henna used to prepare two dilutions of bioinsecticides.

- The in vitro anti-insecticide activity of essential oil was tested against diferents stages of the white scale the results were statistically interpreted.

- The treatmemt C2 (20\% of essential oil) induce mortality of larvae and adult stage delayed by one day from the $\mathrm{C}+$ (insceticide).

\section{ABOUT AUTHORS}

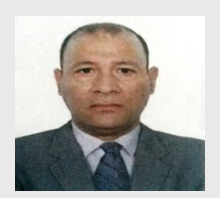

Belhamra M: is currentely Professor at Agronomic sciences department of Biskra university, He is a national expert in the aera of wildlife in danger of extinction in the Ministry of Higher education and scientific research.

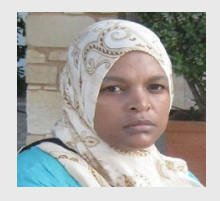

Benaissa K: is currently Asst professor at Agronomic sciences department of Biskra university. Algeria. She is pusruing her Ph D at DEDSPAZA, Biskra University Algeria. She has experience in the cultivation of medicinal plant of arid regions.

Cite this article: Benaissa K, Belhamra M. Contribution to a Study of the Effect of the Essential Oil of Henna (Lawsonia inermis L), on the Biological Aspect of White Scale (Parlatoria blanchardi targ) of Date Palm. Indian J of Pharmaceutical Education and Research. 2017;51(3)Suppl:S309-12. 